\title{
O LIMIAR DA HUMANIZAÇÃO NO ROMANCE CAIM DE JOSÉ SARAMAGO
}

\author{
Nivaldo Medeiros Diógenes ${ }^{1}$
}

RESUMO: Este artigo pretende realizar uma análise do romance Caim, a partir de elementos que constituem a própria obra do autor. Também, recorremos, como fundamentação teórica, ao conceito de limiar, como um primeiro recurso que deixa ver uma literatura tipicamente criada por José Saramago. PALAVRAS-CHAVE: José Saramago, Romance, Caim, Limiar.

ABSTRACT: This article seeks to develop a novel analysis of Caim, from elements that constitute the author's own work. Also, we employed, as a theoretical foundation to the concept of threshol, as a first feature that lets you see in the literature typically created by José Saramago.

KEYWORDS: José Saramago, Novel, Caim, Threshol.

Estamos sob a condição de testemunhas de um período em que as incertezas estão presentes em qualquer segmento cultural, se observado com mais cuidado. Diante desse quadro, pretendemos demonstrar alguns aspectos relevantes que, entre a ruptura e a continuidade, podem ser visualizados como insólitas construções que formam o tecido artístico do romance Caim de José Saramago.

A obra em destaque apresenta algumas peculiaridades de uma fase distinta da produção artística saramaguiana. Porém, há certa parcela de leitores que não concordaria com esse ponto de vista. A exemplo disso citamos o biógrafo João Marques Lopes, ponderando que,

\begin{abstract}
Em Caim, o último livro e o que levou menos tempo de elaboração (apenas quatro meses), Saramago retomou a linha voltairiana de O Evangelho segundo Jesus Cristo e tornou a irritar os setores mais conservadores da Igreja Católica (...) Por certo, o livro tem certa dimensão filosófica graças às constantes interpelações e práticas desconstrutivas dos dogmas teológicos do Velho Testamento, retomando o confronto entre a racionalidade e irracionalidade que já chamara várias vezes a atenção de José Saramago. Contudo, nada parece acrescentar de inovador à carreira do autor (LOPES, 2010, p. 171-172).
\end{abstract}

Cumpre reiterar que o ponto de vista do biógrafo não é corroborado por nós, uma vez que sem uma análise mais acurada do texto artístico, a afirmação de que o romance não traz nada de novo não passa de uma centelha duvidosa lançada a campo, que parece estar fundamentada no tempo de produção da obra, já que mereceu um considerável destaque entre parênteses logo no início de seus comentários.

$\mathrm{Na}$ tentativa de mostrar algo com substância, já podemos apontar como inovação patente, ao considerarmos toda a produção romanesca do autor, o uso do recurso da numeração. No romance Caim, há uma sequenciação numérica de 1 a 13, marcando respectivamente os capítulos. Com isso, parece ficar suspensa no ar a sugestão para que se tenha um estranhamento, mormente, quando se recupera o simbolismo negativo que o

\footnotetext{
1 Doutorando na Área de Literatura Portuguesa da Faculdade de Filosofia, Letras e Ciências Humanas da Universidade de São Paulo (USP).
} 
numeral alude, tomando como base a cultura ocidental de uma imago do mau agouro ${ }^{2}$. Por outro lado, não podemos desconsiderar que o ato de numerar é fazer o leitor se localizar, a rigor, é uma forma de tê-lo na mão. A propósito, tal possibilidade correlaciona, nesse sentido, a obra literária Caim ao universo religioso.

O primeiro discurso, o bíblico, que virtualiza a vida de Caim, ineditamente é organizado por meio de números. Lembremo-nos da sequenciação numérica feita com os livros, os capítulos e os versículos. Assim, parece possível pensarmos no romance Caim como uma paródia $^{3}$ da doutrina cristã.

Assim, com o recurso da numeração, por detrás de uma inocente orientação para o leitor, um percurso possivelmente nos conduzirá a uma imagem que deve ampliar, provavelmente de forma polêmica, o discurso religioso e, nesse sentido, fica sugerida a mudança do efeito da paródia, passando a depreciar o discurso base, mesmo fazendo uso de uma prática costumeira da bíblia.

Podemos afirmar que o início do romance já acontece com a epígrafe, uma vez que a citação do livro dos Hebreus (capítulo 11, versículo quatro), pertencente ao Novo Testamento, é portadora de uma renovação de significado, posto que suscita uma visão de mundo crítica. Para tanto, observemos o fragmento a seguir.

Pela fé, Abel ofereceu a Deus um sacrifício melhor do que o de Caim. Por causa da sua fé, Deus considerou-o seu amigo e aceitou com agrado as suas ofertas. E é pela fé que Abel, embora tenha morrido, ainda fala.

(Hebreu, 11,4)

LIVRO DOS DISPARATES

Consideremos uma questão importante, aqui. É sabido que o episódio dos irmãos Caim e Abel é encontrado primeiramente no Velho Testamento, mas, no caso do romance de José Saramago, a abertura de sua obra recupera tal fato por meio do Novo Testamento. Com isso, o aparente sombreamento dos relatos do Velho Testamento soa insolitamente, na epígrafe, como uma possível visão de mundo do autor incrustada.

Erich Auerbach aponta que "o Velho Testamento, à medida que o relato avança, aproxima-se cada vez mais do histórico.” (AUERBACH, 2009, p. 15), enquanto o Novo Testamento caracteriza-se por relatar "acontecimentos que se desenvolvem no plano da vida cotidiana"(Ibidem, 2009, p. 37). Dessa forma, o Novo Testamento, escrito no mesmo instante em que os acontecimentos e as transformações ocorriam, é importante na formação das "bases

\footnotetext{
${ }^{2}$ Além disso, o número treze é significativo, também, quando o relacionamos com a bíblia, pois retoma a imagem das 13 jarras encontradas em Nag Hammadi por Mahammed Ali Samman, contendo os códices de papiro (os textos apócrifos) em que foram contabilizados 113 livros, sendo 52 em relação ao Velho Testamento e 61 em relação ao Novo Testamento.

${ }^{3}$ Consideramos, nesse momento, a "paródia", como um texto que está ao lado de outro, a partir do termo cunhado por Linda Hutcheon, em que a paródia é percebida como um canto ao lado de outro.
} 
para essa exibição de atrocidades físicas.”(p.55). Daí a referência utilizada por Saramago, "livro dos disparates", sugestivamente grafado em letras maiúsculas, a corroborar a ideia do absurdo de tal referência, posto que o livro dos Hebreus foi escrito para pessoas que estavam em perigo de fazer uma troca absurda. Logo, como alguém que morreu pode continuar a falar?

Saramago, portanto, abre a possibilidade de lermos uma problematização do canônico discurso religioso, enfatizando por meio da nulidade humana com a morte, uma terceira margem. Entende-se que a função do Velho Testamento é a de nos criar uma espécie de história dos acontecimentos, enquanto o Novo Testamento recupera os mesmos episódios por meio de uma reconstrução fabular da narrativa, impregnada com a ideologia cristã. Agora, para nós, esse novo discurso aludido em Caim pode direcionar o leitor por uma linha oblíqua capaz de curto-circuitar literariamente aquilo que se entende por verdade religiosa, uma vez que qualquer episódio do Novo Testamento é passível de uma nova versão para os fatos, posto que podemos entendê-la como uma criação literário-religiosa humana.

No entanto, o trabalho artístico de reconstrução de uma personagem bíblica por meio da literatura, desencadeia uma preocupação crítica com relação à aproximação entre universos aparentemente separados por um espaço abismal. Nesse sentido, as palavras de Northop Frye ressaltam que,

Em nossa cultura, o livro sagrado fundamental é a Bíblia cristã, que é também, provavelmente, no mundo, o livro sagrado mais sistematicamente construído. Dizer que a Bíblia é 'mais' do que uma obra literária é dizer meramente que são possíveis outros métodos de abordagem. Nenhum livro poderia ter tido influência na literatura sem ter qualidades literárias, e a Bíblia é uma obra literária desde que seja examinada por um crítico literário (FRYE, 1978, p. 309).

Assim, com a análise da epígrafe temos o estabelecimento de um posicionamento crítico do autor em relação à dominação que o discurso bíblico-ideológico estabelece e, possivelmente, a valoração da bíblia, enquanto livro que difunde os conceitos religiosos pela opressão, a partir da imagem de Deus e segundo a visão saramaguiana, pode vir a ser deteriorada. Diante dessa possibilidade de análise, observemos o excerto a seguir.

Dos escritos em que, ao longo dos tempos, vieram sendo consignados um pouco ao acaso os acontecimentos destas remotas épocas, quer de possível certificação canónica futura ou fruto de imaginações apócrifas e irremediavelmente heréticas, não se aclara a dúvida sobre que língua terá sido aquela, se o músculo flexível e húmido que se mexe e remexe na cavidade bucal e às vezes fora dela, ou a fala, também chamada idioma, de que o senhor lamentavelmente se havia esquecido e que ignoramos qual fosse, uma vez que dela não ficou o menor vestígio, nem ao menos um coração gravado na casca de uma árvore com uma legenda sentimental, qualquer coisa no gênero amo-te eva. Como uma coisa em princípio, não deveria ir sem a outra, é provável que um outro objectivo do violento empurrão dado pelo senhor às mudas línguas de seus rebentos fosse pô-las em contacto com os mais profundos interiores do ser corporal, as chamadas incomodidades do ser, para que no porvir, já com algum conhecimento de causa, pudessem falar da sua escura e labiríntica confusão a cuja janela, a boca, já começavam elas a assomar (SARAMAGO, 2009, p.9-10). 
É importante destacar que temos, no fragmento selecionado, uma preocupação flagrante com a falta de comprovação que justifique uma possível presença divina, iniciando com o milagre da construção do mundo até a presença dos primeiros seres humanos. Vale destacar que tal sensação de desconfiança por falta de uma prova cabal da existência divina, polêmico e literariamente afeta a validação do Velho Testamento. Nesse sentido, o que parece sugerido, por meio dessa lacuna "científica" e do embate entre o relato e a escrita, como atribuições da presença humana, a colocação sob suspeita de Deus, enquanto ser onisciente.

A presença do homem, no romance Caim, portanto, não é velada continuamente por Deus ao longo dos dias de permanência no Paraíso. Deus teria outros paraísos para cuidar, com outros seres, talvez, assim, a criação humana conhecida fica à deriva, o homem não é o centro das atenções divinas.

Quanto ao senhor e às suas esporádicas visitas, a primeira foi para ver se adão e eva haviam tido problemas com a instalação doméstica, a segunda para saber se tinham beneficiado alguma coisa da experiência da vida campestre e a terceira para avisar que tão cedo não esperava voltar, pois tinha de fazer a ronda pelos outros paraísos existentes no espaço celeste. De facto, só viria a aparecer mais tarde, em data de que não ficou registo, para expulsar o infeliz casal do jardim do éden pelo crime nefando de terem comido do fruto da árvore do conhecimento do bem e do mal (Ibidem, 2009, p. 12).

Por meio da ironia, a preocupação do criador em relação à sua criação fica evidente, ou seja, não é o único foco. Vale destacar também que a postura exacerbadamente rígida de Deus, sugerida pelo narrador, vem a ser o resultado de uma relação ausente, culminando com a desproporcionalidade de se entender como crime o ato de comer um fruto e por ele ser expulso, no caso de Adão e Eva. Parece termos em vista, portanto, a noção de que o "nefando crime" se dá tão somente por um capricho divino pelo descumprimento de uma ordem.

Corrobora-se, então, por meio da sobreposição irônica do discurso literário, uma vez mais, a presença de uma outra voz que polemiza o discurso religioso inicial, dando indícios de uma insatisfação que se assume como compromisso de denúncia, por outro lado, percebe-se a tentativa de se criar uma nova ordem, como podemos ver a seguir.

Antes de prosseguirmos com esta instrutiva e definitiva história de caim a que, com nunca visto atrevimento, metemos ombros, talvez seja aconselhável, para que o leitor não se veja confundido por segunda vez com anacrónicos pesos e medidas, introduzir algum critério na cronologia dos acontecimentos. Assim faremos, pois, começando por esclarecer alguma maliciosa dúvida por aí levantada sobre se adão ainda seria competente para fazer um filho aos cento e trinta anos de idade. À primeira vista, não, se nos ativermos apenas aos índices de fertilidade dos tempos modernos, mas esses cento e trinta anos, naquela infância do mundo, pouco mais teriam representado que uma simples e vigorosa adolescência que até o mais precoce dos casanovas desejaria para si. Além disso, convém lembrar que adão viveu até aos novecentos e trinta anos, pouco lhe faltando, portanto, para morrer afogado no dilúvio universal, pois finou-se em dias da vida de lamec, o pai de noé, futuro construtor da arca. Logo, teve tempo e vagar para fazer os filhos que fez e muito mais se estivesse para aí virado. Como já dissemos, o segundo, o que viria depois de caim, foi abel, um moço aloirado, de boa figura, que, depois de ter sido objeto das melhores provas de estima do senhor, acabou da pior forma. Ao terceiro, como também ficou dito, chamaram-lhe set, mas esse não entrará na narrativa que vamos compondo passo a passo com melindres de 
historiador, por isso aqui o deixamos, só um nome e nada mais. Há quem afirme que foi na cabeça dele que nasceu a ideia de criar uma religião, mas desses delicados assuntos já nos ocupámos avonde no passado, com recriminável ligeireza na opinião de alguns peritos, e em termos que muito provavelmente só virão a prejudicar-nos nas alegações do juízo final quando, quer por excesso quer por defeito, todas as almas forem condenadas (p. 13-14).

Aqui, como já antecipamos, fica evidente a preocupação do narrador em deixar clara a volição de recriar a história que retrata a vida de Caim. Contudo, relembremos que essa nova produção coloca em xeque o Velho Testamento, como fonte de valor histórico da criação divina, e o Novo Testamento, como recriação ideológica para cristalizar o poder de uma primeira produção. Nesse sentido, parece claro que a reconstrução da vida de Caim só pode se dar por um viés estritamente humanizador e laico. A propósito, como nos ensina Marlise Vaz Bridi, a narrativa saramaguiana privilegia, "como construção ficcional", uma "humana interpretação de tudo quanto há, houve ou haverá", enquanto "sagrado exercício de liberdade". (BRIDI, 1998, p. 113)

Por outro prisma de análise, cumpre pensar, também, no romance como uma oportunidade que o narrador confere à personagem. E, com isso, alguns aspectos da Pósmodernidade, período que circunscreve a produção saramaguiana, podem ser mascarados por uma voz que por muito tempo foi olvidada e desprestigiada pela tradição bíblica. Aliás, com o fragmento que se segue, temos o momento primordial para o desencadeamento desse aspecto na narrativa.

Cinquenta anos e um dia depois desta afortunada intervenção cirúrgica com a qual se iniciara uma nova era na estética do corpo humano sob o lema consensual de que tudo nele é melhorável, deu-se a catástrofe. Anunciado por um estrondo de trovão, o senhor fez-se presente. Vinha trajado de maneira diferente da habitual, segundo aquilo que seria, talvez, a nova moda imperial do céu, com uma coroa tripla na cabeça e empunhando o ceptro como um cacete. Eu sou o senhor, gritou, eu sou aquele que é. O jardim do éden caiu em silêncio mortal, não se ouvia nem o zumbido de uma vespa, nem o ladrar de um cão, nem um pio de ave, nem um bramido de elefante. Apenas um bandada de estorninhos que se havia acomodado numa oliveira frondosa que vinha dos tempos da fundação do jardim levantou voo num só impulso, e eram centenas, para não dizer milhares, que quase obscureceram o céu. Quem desobedeceu às minhas ordens, quem foi pelo fruto da minha árvore, perguntou deus, dirigindo directamente a adão um olhar coruscante, palavra desusada mas expressiva como as que mais o forem. Desesperado, o pobre homem tentou, sem resultado, tragar o bocado de maçã que o delatava, mas a voz não lhe saiu, nem para trás nem para diante. Responde, tornou a voz colérica do senhor, ao mesmo tempo que brandia ameaçadoramente o ceptro. Fazendo das tripas coração, consciente do feio que era pôr as culpas em outrem, adão disse, A mulher que tu me deste para viver comigo é que me deu do fruto dessa árvore e eu comi. Revolveu-se o senhor contra a mulher e perguntou, Que fizeste tu, desgraçada, e ela respondeu, A serpente enganou-me e eu comi, Falsa, mentirosa, não há serpentes no paraíso, Senhor, eu não disse que haja serpentes no paraíso, mas digo sim que tive um sonho em que me apareceu uma serpente, e ela disse-me (SARAMAGO, 2009, p. 16-17).

É importante destacar, aqui, desse excerto, o papel importantíssimo e, para nós, pouco estudado, que a palavra "catástrofe", se entendida como um fenômeno distinto, parece assumir para a continuidade da narrativa. Relembremos que, segundo os estudos aristotélicos, tem-se como um correlato ao pathos, assumindo a condição de uma das partes que compõe a 
tragédia. No entanto, no fragmento acima, a catástrofe não tem essa conotação apenas, ao pensarmos como desencadeadora de mortes. Em outra esfera de análise, podemos pensá-la como elemento de transformação, marcando uma nova condição para aqueles que sofrerão com as intempéries acionadas. Em verdade, é possível pensarmos a catástrofe como o estopim que conduz o sujeito, em transição, a passar por diversos limiares ${ }^{4}$, que, por sua vez, sugerem momentos invariavelmente críticos para as personagens que estão circunscritas em seus domínios. Isso fica mais evidente ao observarmos o recorte textual seguinte.

E houve o dia em que adão pôde comprar um pedaço de terra, chamar-lhe sua e levantar, encostada a uma colina, uma casa de toscos adobes(...) Enquanto abel preferia a companhia das ovelhas e dos cordeiros, as alegrias de caim iam todas para as enxadas, a forquilhas e as gadanhas, um, fadado para abrir caminho na pecuária, outro, para singrar na agricultura. Há que reconhecer que a distribuição da mão-de-obra doméstica era absolutamente satisfatória, uma vez que cobria por inteiro os dois mais importantes sectores da economia da época (Ibidem, 2009, p. 31-32).

Lembremos que, na tradição bíblico-cristã, Adão e Eva foram expulsos do Paraíso. Diante desse quadro, uma nova condição, fora do Éden, é, a rigor, um momento de crise para sujeitos desacostumados com a preocupação em atender às necessidades humanas de sobrevivência (fome, sede, frio etc), posto que a descrição referida por Saramago virtualiza o momento em que Adão se encontra como um ser humano comum. Encontrar-se à deriva em um novo mundo desconhecido problematiza a consciência da personagem para a manutenção da sua vida e, então, torna-se fundamental ter que aprender a lidar com a situação do momento. Isso fica evidente quando se anuncia o momento da compra de um pedaço de terra. E, por consequência, a estabilização de Adão, deixando de ser apenas um marido, para acompanhar o nascimento de seus filhos, gera uma nova fase em sua existência, em relação à mudança brusca de vida.

Ao levantarmos a possibilidade de se vislumbrar nesse romance um latente percurso de humanização e, consequentemente, propiciar uma segunda oportunidade para o protagonista, devemos, primeiramente, observar as significações que a relação do homem (Caim) com o trabalho agrícola podem sugerir. Para tanto, segue um trecho com algumas considerações de Mikhail Bakhtin com essa abordagem.

(...) o elemento do trabalho agrícola cria uma ligação real e uma comunhão dos fenômenos da natureza com os acontecimentos da vida humana; além disso, o que é particularmente importante, o trabalho agrícola transforma todos os aspectos da vida cotidiana, retira-lhes seu caráter privado, puramente utilitário, chão transforma-os em acontecimentos essenciais da existência (BAKHTIN, 1988, p. 335).

\footnotetext{
${ }^{4}$ Procuraremos com a tese de doutorado aprofundar as pesquisas em torno desse conceito, mas, nesse estudo, entendemos o limiar como um espaço apto ao desencadeamento de crises. Segundo Teilhard de Chardin, "a vida constitui um limiar de descontinuidade" que, por sua vez, "revela o começo de uma nova ordem" (CHARDIN, 2006, p.84). Assim, na obra estudada aqui, os limiares assumidos e ultrapassados são, a rigor, novas fases necessárias para a transformação e, consequentemente, a melhoria do homem Caim.
} 
De posse de tais informações, torna-se possível, agora, pensarmos nas ferramentas agrícolas, em um prisma simbólico, como utensílios significativos de um percurso sugestivo, desencadeando a imagem de uma vida peculiar em relação à construída para Caim no discurso bíblico-religioso.

Assim, a enxada retomaria a prática e, consequentemente, um homem primitivo, que constituía sua ferramenta com pedra lascada mais um pedaço de madeira denominado embira. Portanto, podemos pensar na enxada como um elemento capaz de fincar o homem à terra, na projeção do trabalho e na criação da família do agricultor, a constituição de um grupo social, logo, as aldeias, vizinhanças, compadrios, vilas, cidades e, por fim, a civilização. Em suma, além de trazer à tona o simbolismo do trabalho, a enxada pode ser associada a uma cultura como elemento primevo da humanidade.

A forquilha recupera um simbolismo feminino devido à sua forma, pois, temos a associação com o formato da região do baixo ventre da mulher. Vale dizer, também, que ela pode ser divida em três partes: a) ponteira, base de uma vida pioneira com o trabalho agrícola - sem máculas, no caso de Caim; b) haste, como o caminho reto, ao se pensar na ação de andar e semear o solo, por outro lado, os nós da haste podem ser vinculados às dificuldades da vida; c) a forquilha, que, em seu formato, recupera a ideia de vitória, partindo para uma vida digna, honesta e profícua.

A gadanha corrobora a noção de morte, quando a associamos com a colheita dos cereais, mas, ainda assim, é esse ato de morte que possibilita a manutenção da vida, com o alimento colhido, por exemplo, o trigo, a produzir o pão.

Portanto, as ferramentas supracitadas, em verdade, são capazes de virtualizar um percurso de vida que, por meio do simbolismo renovado, fazem do trabalho agrícola desempenhado por Caim tornar-se um modelo de vida a ser seguido. Também destacamos, como outra leitura, a imagem do percurso da vida íntegra até o momento da morte.

No romance Caim, é por meio do trabalho agrícola que fica estabelecida a conexão entre a personagem e a natureza, criando as condições fundamentais para que se veja um ser diferenciado e vinculado à vida, diferentemente do que lhe fora estabelecido pela perspectiva religiosa.

É possível dizer, a essa altura da análise, que Caim recupera a noção de um homem diferenciado, um ser humano, de fato, ou, pelo menos, de um que traz uma formação significativa aos nossos olhos. Vejamos como tal aspecto pode ampliar, de forma relevante, as significações ao pensarmos tal fenômeno como o anúncio de uma ritualização tão cara aos homens do passado. 


\begin{abstract}
Apesar de o tempo não estar demasiado frio, a túnica molhada, pegada à pele, causava-lhe arripios. Pensou que despindo-a mataria dois coelhos de uma cajadada, primeiro porque se acabariam os frios, e também porque a túnica, sendo feita de pano mais fino que grosso, em pouco tempo secaria. Assim fez e imediatamente se sentiu melhor. É verdade que não lhe pareceu bem ver-se nu como tinha vindo ao mundo, mas estava sozinho, sem testemunhas, sem ninguém que lhe pudesse tocar (SARAMAGO, 2009, p. 41).
\end{abstract}

É bastante significativa a imagem que o narrador apresenta para nós, uma vez que a nudez, em tela, parece retomar ritualisticamente um momento especial. O fato de Caim estar nu parece estabelecer uma posição de vinculação entre o homem e a natureza ${ }^{5}$, sob essa condição a personagem está em seu estágio primevo enquanto candidato a ser humano, aquele em que não há o mascaramento de sua personalidade por meio de roupas ou outros tipos de coberturas. Nessa condição de nudez, muitos rituais selecionam seus neófitos dentre os profanos. No caso do romance, parece claro termos a sugestão do início da transformação de um assassino, que, a partir desse momento, sob a condição de uma vida significativa, atravessará níveis de provação para findar em uma possível condição melhor.

Passemos a observar, com o fragmento que se segue, a próxima fase na vida ritualística de Caim.

Estava porém escrito que a vida de caim não se acabaria aqui, sobretudo porque não teria valido a pena que o senhor tivesse perdido tanto tempo a amaldiçoá-lo se era para vir morrer neste páramo. O aviso veio de baixo, dos fatigados pés que haviam tardado a perceber que o chão que pisavam era já outro(...) caim, sem saber como nem quando, tinha achado um caminho (Ibidem, 2009, p. 43-44).

Podemos dizer que esse trecho selecionado é fundamental, mormente, quando pensamos na carga de significação que alguns elementos sugerem. Primeiramente, com a imagem dos pés e a perspectiva de uma viagem em busca de algo incerto, mas, no caso de Caim, sobressai uma outra imagem à medida que a personagem deva encontrar um caminho. Tal elemento, o caminho, traz, em si, um simbolismo muito amplo, posto que é por meio dessa jornada que o sujeito apresentará condições de alargar a experiência em busca de uma melhoria. Não obstante, a condição de viajante mostra que Caim está em processo, isso porque, na primeira interpelação com relação ao seu nome, que lhe é feita no trajeto, a resposta foi "Abel é o meu nome, disse caim”(p. 46). Assim parece evidente que Caim ainda está preso ao seu passado, a morte do irmão se agiganta em seu imaginário e a condição miserável que os seus pés se encontraram é um indício do sofrimento necessário para que se desvincule daquele passado reprovável. Por isso, há a impossibilidade de se apresentar como é, ou seja, Caim.

Na continuação da viagem, observemos outro ponto muito importante na transformação do protagonista.

5 Segundo Mike Featherstone, "a natureza exercerá claramente um impacto sobre a vida cotidiana" (FEATHERSTONE, 1997, p. 85), assim, é possível ampliarmos tal condição com o efeito ritualístico na busca por uma vida diferenciada e significativa para a personagem Caim. 
Enquanto o falso abel vai andando em direcção à praça onde, no dizer do velho, se encontrará com o seu destino, atendamos à pertinentíssima observação de alguns leitores vigilantes, dos sempre atentos, que consideram que o diálogo que acabámos de registar como acontecido não seria historicamente nem culturalmente possível, que um lavrador de poucas e já nenhumas terras, e um velho (com duas cabras atadas a um baraço) de que não se conhecem o ofício nem benefício, nunca poderiam pensar e falar assim(...) O que fizemos foi simplesmente passar ao português corrente o duplo e para nós irresolúvel mistério da linguagem e do pensamento daquele tempo (p.46-47).

Aqui, já é deflagrada a importância simbólica que a praça vai assumir na narrativa e, consequentemente, na vida de Caim, ou seja, um local em que se irá encontrar com o seu destino. De fato, é por meio de um trabalho que tal condição parece ser apontada como veremos no próximo fragmento.

O olheiro perguntou, que sabes tu fazer, e caim respondeu, Desta arte, nada, sou lavrador, mas imagino que mais dois braços alguma serventia poderão ter, Dois braços, não, uma vez que não sabes nada do ofício de alvenel, mas dois pés, talvez, Dois pés, para pisar o barro, Ah, Espera aqui, vou falar com o capataz. Retirava-se já, mas ainda voltou a cabeça para perguntar, Como te chamas, Abel, respondeu caim. O olheiro não se demorou muito, Podes começar a trabalhar já, eu levo-te à pisa do barro, Quanto vou ganhar, perguntou caim, Os pisadores ganham todos por igual (p. 48).

Notemos quão significativo é esse trabalho a ser executado por Caim - amassar barro com os pés. Primeiramente parece ficar posto, com o simbolismo do barro, a noção de construção, uma vez que a metáfora religiosa da criação humana torna possível essa leitura. Além disso, podemos entender esse trabalho como a sugestão de uma preparação, com foco nos pés, para algo a ser desempenhado por Caim, isso porque, com a ideia do trabalho e a noção de rotina, é direta a significação de fortalecimento muscular necessário para um andarilho em peregrinação. E, por fim, a condição de preparo físico contínuo que será posto à prova pela personagem Lilith, por meio de um desejo sexual por amassadores de barro que, por algumas vezes, são retirados do trabalho. O mesmo aconteceu a Caim, sendo levado "por elas (duas mulheres, serviçais) a um quarto separado, caim foi despido e logo lavado dos pés à cabeça com água tepida"(p.54). Portanto, Caim atinge uma outra fase na condição humana, o início de uma vida sexual ativa.

Lilith lançou ao homem um olhar apreciador, pareceu gostar do que viu e finalmente disse, Estarás sempre nesta antecâmara, de dia e de noite, tens ali o teu catre e um banco para te sentares, serás, até que eu mude de ideias, o me porteiro, impedirás a entrada de qualquer pessoa, seja que for, no meu quarto, salvo as escravas que o vêm limpar e arrumar (p. 56).

Com esse novo estágio da vida, Caim é destinado a estar continuamente em uma antecâmara, que, simbolicamente, é significativa ao considerarmos como um elemento que sugere um ponto intermediário entre o passado (assassino, amassador de barro), o presente (escravo sexual, um guarda) e o futuro (incerto). Em outra perspectiva de análise, vejamos a 
antecâmara como o espaço propício para que o sujeito reflita e elabore um plano para continuação de sua vida. Nesse caso, fica sugerida a condição intermediária entre Caim, o homem, e a sua nova vida, um legado a ser construído historicamente.

Aplicado, caim esforçava-se sobre o corpo dela, perplexo por aqueles desgarros de movimentos e vozes, mas, ao mesmo tempo, um outro caim que não era ele observava o quadro com curiosidade, quase com frieza, a agitação irreprimível dos membros, as contorções do corpo dela e do seu próprio corpo, as posturas que a cópula, ela mesma, solicitava ou impunha, até o acme dos orgasmos (p. 60).

Parece óbvio que a vida de Caim não poderia se limitar a uma escravidão sexual, mas sim uma condição necessária para ser experienciada e, por isso, significativa, ao que mais adiante, na narrativa, se saberá, isto é, de tais contatos sexuais Caim torna-se pai. A condição de estar em uma antecâmara sugere, também, o período intermediário entre o jovem caim e, futuramente, o pai. No entanto, tal vida aparentemente tranquila e prazerosa não é suficiente para que Caim abandonasse sua jornada de transformação, daí a retomada de seu trajeto com o excerto que se segue.

Caim tocou o jumento com os calcanhares, atravessou a praça (...) Caim tocou outra vez o jumento e em pouco tempo encontrou-se em campo aberto(...) Ao menos, desta vez não lhe faltará comida, os alforges vêm cheios até à boca, lembrança amorosa de lilith que, pelo visto, não nos saiu tão má dona de casa como pelos seus dissolutos costumes poderia pensar-se(...) O caminho subia e subia, e o jumento, que bem vistas as coisas, de burro não tinha nada, avançava aos ziguezagues, ora para cá, ora pra lá(...)E então, ó surpresa, ó pasmo, ó estupefacção, a paisagem que caim tinha agora diante de si era completamente diferente(...) Era como se existisse uma fronteira, um traço a separar dois países, Ou dois tempos(...)é a sua primeira viagem ao estrangeiro, portanto é natural surpreender-se, outra terra, outra gente, outros céus e outros costumes(...) Então estamos no futuro, perguntamos nós, é que temos visto por aí uns filmes que tratam do assunto, e uns livros também (p. 7477).

Caim agora tem ao seu lado um animal que fará parte de sua vida de viajante - o jumento. Cabe lembrar a carga simbólica que esse animal recupera com a noção de humildade. A propósito, isso já é aludido com a tradição cristã, quando relembramos as imagens de Jesus Cristo em peregrinação com esse animal. Ainda assim, marca-se algo muito importante com o fragmento supracitado, ou seja, o percurso nas viagens de Caim, pelo tempo e espaço. É uma condição fantástica da narrativa, que não parece necessitar de maiores explicações, mas é importante destacar a construção mimética para que se entenda a realidade de um tempo mágico-religioso e, assim, equipara-se o romance Caim com a condição mágicoreligiosa bíblica. Parece claro, estarmos diante de uma busca que heroiciza Caim, à medida que a melhoria de condição humana vai se tornando familiar a nós. Isso porque "A ênfase na vida heroica reside na coragem de lutar por metas extraordinárias e realizá-las, na busca da virtude, glória e fama, que contrasta com a busca menor e cotidiana da riqueza, da propriedade e do amor terreno" (FEATHERSTONE, 1997, p. 87).

A essa altura da narrativa, surge a motivação que impulsiona Caim a buscar uma 
condição humana necessária, pois, a história humana é "a história dos seus desentendimentos com deus, nem ele nos entende a nós, nem nós o entendemos a ele (SARAMAGO, 2009, p.88). Com isso, a narrativa parece sugerir a busca de uma revalidação do humano, a criação, para travar dialogicamente um contato com o seu criador, Deus.

Assume-se, assim, a imagem de uma narrativa polêmica diante da postura de Deus ante a sua criação, assim, como poderemos ver no próximo fragmento, a narração desse sagrado passado bíblico, no romance Caim, ganha uma outra dimensão.

Naquela época as maldições eram autênticas obras-primas literárias, tanto pela força da intenção como pela expressão formal em que se condensavam, não fosse josué a crudelíssima pessoa que foi e hoje até poderíamos tomá-lo como modelo estilístico, pelo menos no importante capítulo retórico das pragas e maldições tão pouco frequentado pela modernidade (Ibidem, 2009, p. 111-112).

É flagrante o desconforto com relação às maldições, que, amiúde, fazem parte de uma espécie de retórica do medo tão cara à narrativa bíblica, nesse sentido, é por meio das viagens e passagens mais periclitantes que a imagem de Deus, para a personagem Caim, vai ganhando conotações de um ser injusto e pouco sentimental em relação à sua criação. A propósito, esse Deus é tão cruel a ponto de matar e apostar para ver se a sua criação lhe é submissa. Há que se mencionar que o efeito de um Deus tão perverso se dá por meio de um recurso assaz interessante, ou seja, o adensamento histórico dos fatos para que se tenha consciência da empáfia de Deus como gestor de um mundo pouco bondoso e harmônico. Assim, com essa experiência retida em seu imaginário, com o fragmento a seguir, temos o retorno de Caim para uma outra fase.

No que se refere a caim, é natural que não se tenha esquecido do caminho para chegar ao palácio. Quando ali entrar, estará em seu poder mudar de rumo, abandonar os outros presentes que o esperam antes do hoje e depois do hoje, e regressar a este passado por um dia que seja, ou dois, talvez mais, mas não para todo que falte viver, pois o seu destino ainda está por cumprir, como a seu tempo saberá. Caim tocou de leve com os calcanhares as ilhargas do jumento(...)O escravo subiu a escada e voltou daí a pouco acompanhado por um rapazinho que devia ter uns nove ou dez anos, É meu filho pensou caim (p.124-125).

Caim, agora, não está apenas em transformação como homem, mas já é pleno ao saber da sua condição de pai. Tem-se, portanto, a concretização do simbolismo da criação do barro, a geração da vida (a sua obra), por um meio peculiarmente animal e humano, o sexo. Com isso, distingue-se da criação mágica de Deus, a figura humana. Aqui, marca-se, uma vez mais, a evolução da condição humana de Caim. Para tanto, com esse retorno, destacamos o momento em que Caim conta as experiências que viveu para sua amante Lilith.

Queres dizer que adivinhaste o futuro, Não adivinhei, estive lá, Ninguém pode estar no futuro, Então não lhe chamemos futuro, chamemos-lhe outro presente, outros presentes, Não percebo, Também a mim ao princípio me custou a compreender, mas depois vi que, se estava lá, e realmente estava, era num presente que me encontrava, o que havia sido futuro tinha deixado de o ser, o amanhã era agora, Ninguém vai acreditar em ti, Não penso em fazer isto a mais ninguém, $O$ teu mal é que não trazes contigo nenhuma prova, um 
objecto qualquer desse outro presente, Não foi um presente, mas vários, Dá-me um exemplo. Então caim contou a lilith o caso de um homem chamado abraão a quem o senhor ordenara que lhe sacrificasse o próprio filho, depois o de uma grande torre com a qual os homens queriam chegar ao céu e que o senhor com um sopro deitou abaixo, logo o de uma cidade em que os homens preferiam ir para a cama com outros homens e do castigo de fogo e enxofre que o senhor tinha feito cair sobre eles sem poupar as crianças, que ainda não sabiam o que iriam querer no futuro, a seguir o de um enorme ajuntamento de gente no sopé de um monte a que chamavam sinai e a fabricação de um bezerro de ouro que adoraram o por isso morreram muitos, o da cidade de madian que se atreveu a matar trinta e seis soldados de um exército denominado israelita e cuja população foi exterminada até à última criança, o de uma outra cidade, chamada jericó, cujas muralhas foram deitadas abaixo pelo clangor de trombetas feitas de cornos de carneiro e depois destruído tudo o que tinha dentro, incluindo, além de homens e mulheres, novos e velhos, também os bois, as ovelhas e os jumentos. Foi isto o que eu vi, rematou caim(...)Ao contrário do que costuma dizer-se, o futuro já escrito, o que nós não sabemos é ler-lhe a página, disse caim enquanto perguntava a si mesmo aonde teria ido buscar a revolucionária ideia (p 127-128).

Eis que surge novamente a importância do relato como fundamentação dos ocorridos diante da possível experienciação de Caim e, consequentemente, marcam-se traços de um heroísmo insólito, mas acentuadamente humano e bom como pode ser visto abaixo.

Apesar de assassino, caim é um homem intrinsecamente honesto, os dissolutos dias vividos em contubérnio com lilith, ainda que censuráveis do ponto de vista dos preconceitos burgueses, não foram bastantes para perverter o seu inato sentido moral de existência, haja visto o corajoso enfrentamento que tem mantido com deus, embora, forçoso é dizê-lo, o senhor nem de tal se tenha apercebido até hoje, salvo se se recorda a discussão que ambos travaram diante do cadáver ainda quente de abel (p. 143).

Caim já é diferente, e tem outra posição ante a morte, agora, é um ser capaz de perdoar o seu algoz, bastante diferente, nesse ponto, da imagem criada por Saramago de Deus ao longo da narrativa. As responsabilidades de um mundo cada vez mais cruel são colocadas no romance, de forma patente, como sendo divinas, posto que existe um Deus incapaz de gerir tais contendas entre os seres. Tamanha ingerência resulta, inclusive, em uma aposta com o diabo para que se prove a fé de um humano, no caso de Job, infestado por doenças a mando de Deus e Caim, sabedor disso, há que observar tudo e calar sob a condição de uma classe diferente da de seu patrão.

Discreto, como a foragido convém, caim não se aproximou para lhe desejar as melhoras da sua saúde, afinal, este patrão (Job) e este empregado (Caim) nem tinham chegado a conhecer-se, é o mau que tem a divisão em classes, cada um no seu lugar, se possível onde nasceu, assim não haverá nenhuma maneira de fazer amizades entre oriundos dos diversos mundos (p. 144).

É com o relato de um sujeito com experiências de mundo que esse homem torna-se um sujeito bem diferente daquele outro criado na história bíblica. Caim chega ao momento do anúncio da catástrofe das águas do dilúvio, questionando, mesmo que de forma inverossimilhante, o que se tornará uma fundamentação no conhecimento científico moderno.

Então caim disse, Com estas dimensões e a carga que irá levantar dentro, a arca não poderá flutuar, quando o vale começar a ser inundado não haverá impulso de água capaz de a levantar do chão, o resultado será afogarem-se todos os que lá estiverem e a esperada salvação transformar-se-á em ratoeira, Os meus cálculos não me dizem isso, emendou o senhor, Os teus cálculos estão errados, um barco deve ser construído junto à água, não num vale rodeado de montanhas, a uma distância enorme do mar, quando está terminado 
empurra-se para a água e é o próprio mar, ou o rio, se for esse o caso, que se encarregam de o levantar, talvez não saibas que os barcos flutuam porque todo o corpo submergido num fluido experimenta um impulso vertical e para cima igual ao peso do volume do fluido desalojado, é o princípio de arquimedes, Permite, senhor, que eu expresse o meu pensamento, disse noé, Fala, disse deus, manifestadamente contrariado, Caim tem razão(p.152).

Tem-se, portanto, a contribuição do autor Saramago nesse questionamento da impossibilidade de navegação da arca, mas, ainda assim, é relevante a postura de Caim enquanto um homem diferente em relação a outros momentos da narrativa. A convivência de Caim com a família de Noé marca o início da concretização de um plano meticuloso de assassinato de cada um dos integrante das arca, findando como o instante em que há o reencontro com Deus.

Vindo do escuro interior da arca, caim apareceu no limiar da grande porta, Onde estão noé e
os seus, perguntou o senhor, Por aí mortos(...) Teria de chegar o dia em alguém te colocaria
perante a tua verdadeira face(...) a única coisa que se sabe de ciência certa é que
continuaram a discutir e que a discutir estão ainda. A história acabou, não haverá nada mais
que contar (p. 172).

Observemos quão significativo é esse momento do diálogo final entre Caim e Deus. Isso já fica posto quando Caim sai da escuridão, com todo o simbolismo associado de não conhecimento, para a luz, cabendo a significação da sabedoria, nesse casso, como também com a noção do limiar da porta que flagrantemente anuncia outro momento de crise, mas sem resolução. Esse fim, por meio de uma interpelação que, virtualmente se vincula com o início da narrativa, em que temos a maculação na testa de caim, por não deixar condições de seguir com a possível nova humanidade, gera um vácuo na narrativa bíblica. Consequentemente, por meio de o mecanismo do relato, apesar de ser repudiado como sustentação para a comprovação de uma existência divina, cristaliza Caim como a prova literário-material de uma criação histórico-humanizadora.

Em suma, recuperando a noção do biógrafo que afirma que o romance Caim não traz nada de novo, mas quando analisado, somando-se às outras que seguirão, provavelmente demonstrarão o quanto obliterada é a afirmativa de João Marques Lopes. Ao desbastarmos as camadas mais superficiais do texto, ficam expostas as engrenagens que, ainda que não totalmente inéditas, são suficientemente capazes de deixar ver pontos peculiares, quando pensamos desde a marcação de capítulos, à possibilidade de se pensar em um cronotopo da catástrofe, o limiar (como espaço privilegiado para a produção artística de crises) da humanização etc.

Caim, em verdade, é o último romance de uma obra que ainda tem muito a oferecer, mas para que isso ocorra, é claro, não pode a crítica fechar o círculo das análises. Com essa prática não só reduziríamos, mas também obliteraríamos o que a literatura tem mais belo, ao nosso entender, a renovação contínua das significações. Sendo assim, cabe uma constante 
reflexão, ao modelo de Caim, em busca de uma melhoria humana e, quiçá, da crítica.

\section{Referências bibliográficas}

AUERBACH, Erich. Mimesis: a representação da realidade na literatura ocidental. São Paulo: Perspectiva, 2009.

BAKHTIN, Mikhail. Questões de literatura e de estética. Trad. Aurora Fornoni Bernardini et alii. São Paulo: Hucitec, 1988.

BENJAMIN, Walter. Magia e técnica, arte e política: ensaios sobre literatura e história da cultura. Trad. Sérgio Paulo Rouanet. $7^{\mathrm{a}}$ ed. São Paulo: Brasiliense, 2010.

BRIDI, Marlise Vaz. O evangelho de Saramago: a paixão de Cristo em perspectiva. In: LOPONDO, Lilian. Saramago segundo terceiros. São Paulo: Humanitas, 1998.

CHARDIN, Teilhard de. O fenômeno humano. Trad. Paulo Evaristo Arns. São Paulo: Cultrix, 2006.

ELIADE, Mircea. O sagrado e o profano. Trad. Rogério Fernandes. São Paulo: Martins Fontes, 1992.

FEATHERSTONE, Mike. O desmanche da cultura: globalização, pós-modernismo e identidade. Trad. Carlos Eugênio Marcondes de Moura. São Paulo: Studio Nobel, 1997.

FRYE, Northrop. Anatomia da crítica. Trad. Péricles Eugênio da Silva Ramos. São Paulo: Cultrix, 1973.

HUTCHEON, Linda. Poética do Pós-Modernismo: história, teoria, ficção. Trad. Ricardo Cruz. Rio de Janeiro: Imago1991.

LOPES, João Marques. Saramago: biografia. São Paulo: Leya, 2010.

SARAMAGO, José. Caim. São Paulo: Companhia das Letras, 2009.

WELLEK, René; WARREN, Austin.Teoria da literatura. Trad. José Palla e Carmo. $5^{\mathrm{a} e d .}$ Porto: Europa-América, 1972. 